\title{
Undip Initiative for Sustainability (UNITY): A University Sustainability Program
}

\author{
Ambariyanto Ambariyanto ${ }^{1, *}$, Yos Johan Utama ${ }^{2}$, Mochamad Arief Budihardjo ${ }^{3}$ and Purwanto Purwanto ${ }^{3}$ \\ ${ }^{1}$ Faculty of Fisheries and Marine Sciences, Diponegoro University, Semarang - Indonesia \\ ${ }^{2}$ Faculty of Law, Diponegoro University, Semarang - Indonesia \\ ${ }^{3}$ Environmental Science, School of Postgraduate Studies, Diponegoro University, Semarang - Indonesia
}

\begin{abstract}
Managing a modern university that applies various international standards (world class university) must pay attention to many important factors, including sustainability. Universitas Diponegoro (Undip) Semarang, Indonesia as a public university legal entity that also has a vision of becoming a research university is well aware of the importance of establishing sustainable campus. This paper describes sustainability program of Undip called UNITY, which stands for Undip Initiative for Sustainability. This program refers to five main factors, namely infrastructure, energy and climate, waste, water, and transportation. This paper briefly discuss planned activities of each factor. The program which is fully supported by all components of Universitas Diponegoro, aims to create a campus that is clean, healthy, comfortable, safe and sustainable.
\end{abstract}

Keywords: Unity; campus sustainability; green campus.

\section{Background}

The development of university management system throughout the world is increasingly complex with various issues, especially those related to awareness of the importance of environmental aspects, human rights in addition to the rapid development of science and technology. Current issue of industrial revolution 4.0 also affects the development of universities throughout the world [1]. The influence is not only about the process of education and learning that will change a lot, including infrastructure and other facilities, but also in the management of the campus in general.

University stakeholders are increasingly aware that they need a healthy, clean, safe and comfortable campus [2]. They also demand the availability of sufficient facilities, especially related to technological developments, especially the digital world. Higher education institutions need advance IT facilities that meet their needs [3].

Today's campus managers in modern higher education institutions are not only required to produce graduates who are competent in accordance with the needs of the community as well as innovative research products needed by the market, but also able to establish sustainable campus [4,5]. This situation encourages all modern university managers to innovate in developing programs to meet various international standards in accordance with stakeholders' expectations, including students [6].
Universitas Diponegoro is currently growing rapidly in its efforts to become an excellent research university and become a world-class university through the implementation of various international standard programs [7]. In addition, various aspects related to environmental issues and other aspects such as climate change are increasingly gaining attention as the basis for the development of sustainable campus. To achieve this, an integrated approach is needed to manage the campus environment [8].

This article provides an overview of the programs at Universitas Diponegoro in developing sustainable campus by focusing on five aspects, namely infrastructure, energy and climate, waste, water, and transportation.

\section{Undip Initiatives for Sustainability}

Universitas Diponegoro has a vision to become an excellent research university [7]. This vision has encouraged students and lecturers to carry out research that produces publications, patents and innovation products. It also influenced the university management's policy to provide various facilities and research funds for students and lecturers. This university also has main scientific interest i.e. Coastal Region Eco-development since its situated in coastal area as well as the fact that Indonesia is an archipelagic country [9].

* Corresponding author: ambariyanto@ live.undip.ac.id 
Another change is the increasing number of students and lecturers living on campus to work on various academic activities and those related to research. This development has also created a new awareness of the environmental conditions of the university that are comfortable for them. The comfortable campus development also requires green and intelligence (smart) building which are generally able to regulate temperature and lighting [10]. They are also concerned about the use of natural resources, especially those on campus, such as water, air quality and campus forests.

In regard to Sustainable Development Goals that are currently become international issues, universities must also play an active role in accelerating the achievement of targets (goals). Universitas Diponegoro also applies various policies based on the targets of the SDGs [11].

Based on that awareness, Universitas Diponegoro took the initiative to develop a program towards sustainable campus called Undip Initiatives for Sustainability (UNITY). This program specifically emphasizes five aspects, namely infrastructure, energy and climate, waste, water, and transportation

\subsection{Infrastructure}

Managing the entire campus area by referring to environmental sustainability, requires a detailed understanding of the location and various aspects that affect its condition. Diponegoro University is very concerned about the campus environment, especially related to infrastructure development in accordance with the needs and demands of the university's progress. Undip's vision to become a research university and become a world-class university, requires the development of infrastructure that is sufficient for its needs while meeting various international standards. Undip's policies related to infrastructure include (a) maintaining the highest possible open space, now for all campuses owned by Undip, the area is more than $90 \%$ open space; (b) keep the campus forest area located on two large Undip campuses both on the main campus (Tembalang) and Teluk Awur campus (Jepara); (c) tree planting programs to increase the area covered by trees; (d) developing special forest for rare plants on the main campus; (e) maintain non-forest open space as part of water absorbance.

\subsection{Energy and Climate}

Energy needs, especially electricity at Undip campus continue to increase in accordance with the development of learning activities, as well as research. The addition of laboratory equipments as well as other facilities also requires electrical energy, including for maintenance. Almost all rooms in Undip use air conditioner considering the high temperatures in the tropics, so that the increase in electricity demand is unavoidable [12] which results in increased costs. This has been fully realized by the campus management, so that several programs have been prepared to reduce energy use, especially electricity.
These programs include (a) All new buildings built must apply smart and green building technology; (b) Development of renewable energy utilization such as biogas, solarcell, etc.; (c) All lights in the old building are replaced with energy-saving lamps (LED); (d) Various notification efforts to all personnel at Undip to minimize the use of lights and air conditioners; (e) Use of tools to minimize the use of lights and air conditioners, for example by sensors or cards.

While related to climate change, several programs or policies implemented include: (a) Tree planting activities carried out periodically; (b) Gas emission reduction program, for example the "nebeng" program where to go to campus they urge to go together with friends who have a car or motorcycle, providing shuttle buses or commuter buses from the city government.

\subsection{Waste}

Waste is one of the main problems in environmental management including on campus [7]. The number of activities carried out by students and lecturers both related to academic, research, office and personal activities has increased the amount of waste. The use of plastic in packaging also plays a role in increasing waste.

The challenge that arises is how to be able to implement a zero waste program on campus [13]. To reduce the amount of waste and negative influences on the environment, Undip establishes the following waste management policies [14]: (a) An Integrated Waste Management Team has been established that regulates the entire process of handling waste; (b) all waste is separated by organic, non-organic or hazardous waste; (c) a recycling program is developed through the development of compost from existing waste; (d) for hazardous waste originating from laboratories or hospitals in collaboration with third parties who have licenses to handle this type of waste; (e) providing incinerator facilities to handle special waste, even though it is currently in the licensing process so that it can be used; (f) Notification to lecturers and students to use the paper both sides to reduce paper use; (g) the implementation of e-office in Undip greatly reduces paper use; (h) reducing the use of drinks in plastic bottles or cups, especially during campus meetings.

\subsection{Water}

Water plays a very important role in human life. However, to manage water resources in a sustainable manner it is not easy [15] because human water needs continue to increase. The use of water in Undip continues to increase in line with increased activity on campus. In addition to personal needs, water is also used for laboratory activities and outdoor needs such as watering the plants in the garden. Undip's policy in managing water resources in a sustainable manner with water conservation is carried out through several programs, namely: (a) construction of campus reservoirs to collect water from rivers where the amount of water is abundant during the rainy season; (b) the program for replacing all toilets and sinks in the 
bathroom to use water-saving appliances; (c) planned to develop rain harvesting facilities and reuse (recycle) water from the bathroom; (d) regularly inspect water pipes in the event of a leak immediately repaired; (e) written notification to all units in Undip to minimize water use.

\subsection{Transportation}

Emission reduction is one program to improve environmental quality [16] including on campus. This program is very much related to the regulation of vehicle transportation within the campus area. The large number of students and academics has resulted in increased use of cars and motorbikes. To reduce the emissions produced by these vehicles, Undip has the following policies: (a) provide free shuttle buses from the city to campus and from campus to city; (b) through cooperation with the Semarang city government to provide regular low-cost buses that pass through the campus and several locations in the city; (c) providing bicycles in each faculty or other unit that can be used free of charge by anyone on campus; (d) prohibiting parking in the area on the campus because the parking building has been prepared even though the capacity is limited; (e) prepare a special parking place for disabled; (f) students have a "nebeng" program mentioned above.

\section{Conclusion}

Undip Initiative for Sustainability (UNITY) is a program that focus on addressing environmental related aspects namely infrastructure, energy and climate, waste, water, and transportation in order to achieve Universitas Diponegoro sustainable campus.

\section{References}

1. M. Baygin, H. Yetis, M. Karakose, E. Akin. $15^{\text {th }}$ International Conference on Information Technology Based Higher Education and Training. pp: 1-4). IEEE (2016)

2. Y.J. Utama, Purwanto, A. Ambariyanto. Adv. Sci. Lett. 23: 2584-2585. https://doi.org/10.1166/asl.2017.8712 (2017)

3. K.C. Green, S.W. Gilbert. The magazine of higher learning. 27: 8-18 (1995)
4. J. Mcmillin, R. Dyball, R. J. Educ. Sustain. Dev. 3: 55-64 (2009)

5. M. Thomashow. Sustainability: J. Record, 7: 174-175 (2014)

6. T. Gruber, S. Fuß, R. Voss, M. Gläser-Zikuda. Int. J. Public Sector Manag. 23: 105-123 (2010)

7. Y.J. Utama, A. Ambariyanto. In IOP Conference Series: Earth and Environmental Science 55: 012072.

http://iopscience.iop.org/article/10.1088/17551315/55/1/012072 (2017)

8. H.M. Alshuwaikhat, I. Abubakar. J. Cleaner Product. 16: 1777-1785 (2008)

9. A. Ambariyanto, Y.J. Utama, D. Darsono, B. Setyiono, M. Zainuri, R. Noor. Adv. Sci. Lett. 23: 10061-10063.

doi: https://doi.org/10.1166/asl.2017.10387 (2017)

10. J. Skopek, P. Hajek, J. Tywoniak, A. Lupisek. Cesb 10: Central Europe Towards Sustainable Building-from Theory to Practice, pp:185-188 (2010)

11. Y.J. Utama, A. Ambariyanto, M. Zainuri, D. Darsono, B. Setyono, S.P. Putro. J. Physics: Conference Series. 1025: 012094. IOP Publishing. do: 10.1088/1742-6596/1025/1/012094 (2018)

12. A. Ambariyanto, Y.J. Utama. In E3S Web of Conferences. 31: 01003). EDP Sciences. doi: https://doi.org/10.1051/e3sconf/20183101003 (2018)

13. I.G. Mason, A.K. Brooking, A. Oberender, J.M. Harford, P.G. Horsley. Resources, Conserv. Recycl. 38: 257-269 (2003)

14. Y.J. Utama, A. Ambariyanto, G. Samudro. In E3S Web of Conferences. 48: 04002. EDP Sciences. (2018)

15. N.L. Poff, C.M. Brown, T.E. Grantham, J.H. Matthews, M.A. Palmer, C.M. Spence, R.L. Wilby, M. Haasnoot, G.F. Mendoza, K.C. Dominique, A. Baeza. Nature Climate Change, 6: 25 (2016)

16. I. D Elia, M. Bencardino, L. Ciancarella, M. Contaldi, G. Vialetto. Atmospheric Environ. 43: 6182-6189 (2009) 